\title{
Ergonomic Analysis of Work Fatigue and Eyestrain Among Wig Makers at PT. SCI Indonesia Kupang City
}

\author{
Luh Putu Ruliati ${ }^{*}$, Febri Mahalinda Maisal ${ }^{2}$, Marylin Susanti Junias ${ }^{1}$, Luh Erlanggita \\ Narta Santi ${ }^{3}$
}

${ }^{1}$ Faculty of Public Health, Nusa Cendana University, Kupang, NTT, Indonesia

${ }^{2}$ Student of Magister of Public Health, Nusa Cendana University, Kupang, NTT, Indonesia

${ }^{3}$ Student of Public Health Medical Faculty, Udayana University, Denpasar, Bali, Indonesia

*Corresponding Author. Email: ruliatiluhputu@yahoo.com

\begin{abstract}
Making wigs is a job that requires high accuracy and concentration. If done for a long time with a heavy workload, and work posturethat is not ergonomic can cause work fatigue and eyestrain on workers. The work environment in the form of lighting that does not meet the requirements also affects the health of the worker's eyes. Eyestrain occurs because workers try to see small objects at close range with a long duration of time, causing tension in the eye muscles. Eyestrain can affect the work health and safety of workers, so as to reduce work productivity. This study aims to determine the relationship between work postureand eyestrain, the relationship of workload with eyestrain and the relationship of lighting to eyestrain in wigs of PT. SCI Kupang City. This research is a descriptive analytic study with cross sectional design. The sample in this study were 48 workers at PT. Kupang City SCI taken using Simple Random Sampling technique with data analysis using Chi Square test. Work Attitude, Workload and Lighting in the study are independent variables, while eyestrain and work fatigue are the dependent variable. The results showed that there was a significant association between work posture and work fatigue $(\mathrm{p}=0,000<0,05)$ and eyestrain $(\mathrm{p}=0,011<0,05)$. Workload was also associated with work fatigue $(\mathrm{p}=0,002<0,05)$ but had no relationship with eyestrain $(\mathrm{p}=0,201>0,05)$. The result also found that lighting was significantly related to both work fatigue ( $\mathrm{p}$-value $=0,002<0,05$ ) and eyestrain ( $\mathrm{p}$-value $=0,004<0,05$ ). It is expected that workers work with an ergonomic work posture so that eyestrain can be reduced, utilizing rest time as optimal as possible so that the perceived eyestrain and work fatigue can be reduced. Workers need to work with ergonomic posture, workloads and lighting in order to reduce work fatigue and eyestrain, which may lead to an increase in productivity.
\end{abstract}

Keywords: work posture, workload, lighting, work fatigue, eyestrain

\section{INTRODUCTION}

Occupational Disease (OD) is a disease caused by work and work environment. OD risk factors include: physical, chemical, biological or psychosocial groups in the workplace. These factors in the work environment are the main and decisive causes. Other factors such as individual findings are also in its development among exposed workers [5]. Data on workplace accidents in Indonesia, according to Badan Penyelenggara Jaminan Sosial (BPJS), noted that by the end of 2015 , there were 105,182 work accidents. Meanwhile, cases of severe accidents counted as many as 2,375 cases of the total number of work accidents. In 2016 accidents due to the crisis occurred in 101,367 cases in 17,069 companies out of 359,724 registered companies with 2,382 deaths until November 2016. The main cause of this work is low awareness of Occupational Health and Safety (OHS) in the industry and community paradigm. So far, the application of OHS is a cost burden, not as an investment to prevent work accidents.

Overall, both formal and informal industries in a company are expected to implement OHS for each worker so that health and employment services to increase productivity. Occupational safety and health needs to be regulated in law or regulation so that workers are protected from potential hazards. Workers must be avoided from various threats or factors that can cause work accidents [2].

PT. Sung Cang Indonesia (SCI) is one of the Foreign Investment Companies (FIC) engaged in the Manufacture of Fake Hair (Wigs). This company has spread in various regions in Indonesia; one of which is located in Kupang, East Nusa Tenggara.

All of them have different workloads. Apprenticeship workers and semi-wholesale embroider wigs in small sizes that are half a head. Meanwhile, the wholesale system embroiders wigs in large sizes that are one full head.

Initial surveys that have been conducted at PT. SCI in Kelapa Lima Subdistrict, Kupang City, found several 
health problems related to work fatigue and eyestrain. The results of the interview, found that most workers experience symptoms of work fatigue caused by nonergonomic work attitudes. This is happened because they often work with their head down and a bent sitting position for a long duration of time so that workers experience work fatigue when doing work. The results of the initial interviews also showed that wig-makers also experienced symptoms of eyestrain caused by the distance between eyes and objects that were done too close and had a very small size, thus requiring a high level of accuracy and concentration.

A non-ergonomic work environment also affects one's health at work. Lighting sources with workers have a very close distance that often causes pain in the eyes and unfocused views. Good lighting allows workers to see objects clearly, quickly and without unnecessary effort and vice versa if lighting is inadequate; it will cause eyestrain because it forces the eye muscles to see an object in dim light.

Job work fatigue is a process of decreasing efficiency, work performance, and reduced strength or physical endurance of the body to continue the activities that must be done. According to [12] work fatigue arises because of tension in muscles. There are $80 \%$ of people living after adulthood that feel pain in the back of their body due to various reasons. As a result, $40 \%$ of people are not able to work [11]. Meanwhile, work fatigue in the eyes, according to [8], occurs because a person attempts to see small objects at a close distance with a long time duration that causes tension in the eye muscles (Seko, 2014).

\section{METHOD}

This type of research is a cross sectional study. The study was conducted at PT. SCI, Lasiana Village, Kelapa Lima District, Kupang City. The population consisted of 127 female workers with the sampling technique used was simple random sampling obtained with a sample of 48 workers [10] Data collection techniques are interviews using a questionnaire, measuring light with a lux meter, and documentation using a camera. The data obtained were analyzed analytically to determine the relationship of work attitude, lighting and temperature with fatigue, and eye fatigue in tailors. Hypothesis testing uses the Chi Square statistical test $\left(\mathrm{X}^{2}\right)$, using a significance limit $(\alpha=$ $0.05)$.

\section{RESULTS AND DISCUSSION}

1. Relationship of Work Attitude with Work Fatigue and Eyestrain on Wig Makers at PT. SCI.

Table I. Relationship Of Work Attitude With Work Fatigue And Eyestrain

\begin{tabular}{|c|c|c|c|c|c|c|c|c|c|}
\hline \multirow{3}{*}{$\begin{array}{l}\text { Work } \\
\text { Attitude }\end{array}$} & \multicolumn{6}{|c|}{ Work fatigue } & \multirow{2}{*}{\multicolumn{2}{|c|}{ Total }} & \multirow{3}{*}{$\begin{array}{c}\mathbf{P} \\
\text { Value }\end{array}$} \\
\hline & \multicolumn{2}{|c|}{ Mild } & \multicolumn{2}{|c|}{ Moderate } & \multicolumn{2}{|c|}{ Heavy } & & & \\
\hline & $\mathrm{n}$ & $\%$ & $\mathrm{n}$ & $\%$ & $\mathrm{n}$ & $\%$ & $\mathrm{~N}$ & $\%$ & \\
\hline Risk & 11 & 29,9 & 4 & 8,3 & 4 & 8,3 & 19 & 39,6 & 0,000 \\
\hline $\begin{array}{l}\text { Hight } \\
\text { risk }\end{array}$ & 3 & 6,3 & 15 & 31,3 & 11 & 22,9 & 29 & 60,4 & \\
\hline Total & 14 & 29,2 & 19 & 39,6 & 15 & 31,3 & 48 & 100 & \\
\hline \multirow{3}{*}{$\begin{array}{l}\text { Work } \\
\text { Attitude }\end{array}$} & \multicolumn{6}{|c|}{ Eyestrain } & \multirow{2}{*}{\multicolumn{2}{|c|}{ Total }} & \multirow{3}{*}{$\begin{array}{c}\mathbf{P} \\
\text { Value }\end{array}$} \\
\hline & \multicolumn{2}{|c|}{ Mild } & Mo & rate & \multicolumn{2}{|c|}{ Heavy } & & & \\
\hline & $\mathrm{n}$ & $\%$ & $\mathrm{n}$ & $\%$ & $\mathrm{n}$ & $\%$ & $\mathrm{~N}$ & $\%$ & \\
\hline Risk & 12 & 25,0 & 5 & 10,4 & 2 & 4,2 & 19 & 39,6 & \multirow[t]{2}{*}{0,011} \\
\hline $\begin{array}{l}\text { Hight } \\
\text { risk }\end{array}$ & 5 & 10,4 & 13 & 27,1 & 11 & 22,9 & 29 & 60,4 & \\
\hline Total & 17 & 35,4 & 18 & 37,5 & 13 & 27,1 & 48 & 100 & \\
\hline
\end{tabular}

Table I on hight risk work attitude category, there are 11 workers experienced heavy work fatigue (22.9\%), 15 workers experienced moderate work fatigue $(31.3 \%)$, and 3 workers experienced mild work fatigue $(6,3 \%)$. While in the risk work attitude category, there were 4 workers experiencing severe work fatigue $(8.3 \%), 4$ workers experiencing moderate work fatigue $(8.3 \%)$, and 11 workers experiencing mild work fatigue (29.9\%). Based on the results of the Chi-square test, the significance value of $p$-value is $0.000<0.05$. As a result, there is a relationship between work attitudes and work fatigue in PT. SCI.

In the eyestrain section, work attitude category is hight risk. There are 11 workers experiencing severe work fatigue $(22.9 \%), 13$ workers experiencing moderate work fatigue $(27.1 \%)$, and 5 workers experiencing mild work fatigue $(10.4 \%)$. Whereas in the risk work attitude category there were 2 workers experiencing severe eyestrain $(4.2 \%), 5$ workers experienced moderate eyestrain (10.4\%), and 12 workers experienced mild eyestrain $(25.0 \%)$. Chi-square test results obtained $\mathrm{p}$-value significance value $0.011<0.05$. As a result, there is a relationship between work attitudes and eyestrain in PT. SCI. Work attitude is a picture of the position of body, head, hands, feet, and other limbs while doing work. The attitude of the body when working greatly affects a worker's health. According to [13], work posture is an arrangement of body posture when working. Convenience is created when workers have done a good and safe work attitude. A good work attitude is determined by the movement of organs when working [15].

Unnatural working attitude will cause muscle contraction isometrically (against resistance) in the main muscles that is involved. Unnatural posture can cause the muscles to not work efficiently. Therefore, muscles need more strength to complete the task which can increase the burden that can cause work fatigue and tension in the muscles and tendons [1]

Seeing objects that are being worked requires a high level eyesight accuracy and in a long time, with work that tends to be static or repetitive, requiring workers to get ergonomic work stations to avoid unnecessary efforts. Standards of work facilities (tables and chairs), which is good according to [9], namely the work chair must have a backrest so that workers can take a break for stretching muscles, the chair has a lower back support, and the chair can be set high and low to fit the anthropometry of power work sitting on the chair. Moderation for the table is that the height of the table must be parallel to the chest of the worker so that the worker does the work in an upright position and does not bend; the table has a wider field of work tools, and has a footing for workers' footing. However, based on the results of the research, the facilities used are not in accordance with the existing standards, so as to make workers uncomfortable while doing work. This is what makes workers work with unnatural work attitudes, such as workers who work in a bent position in a static state with a long time span. This will burden the muscular nervous system in the worker causing work fatigue and 
eyestrain at work.

One factor that supports a good work attitude when working is good lighting; if it is not well designed it can cause visual disturbances or work fatigue during work. The influence of lighting that does not meet the requirements will result in disturbances, namely eyestrain resulting in reduced power and efficient work, mental work fatigue, achy complaints in the eye area, headaches around the eyes, damage to the eye senses, and others. The effect of work fatigue on the eye will affect the decrease in work performance including loss of productivity, low quality of work, a lot of mistakes, and increased work accidents. Work fatigue in the eyes, in principle, does not damage the eyes, but will cause discomfort and work fatigue in the eyes [17].

Lighting that does not meet standards is also one of the factors that influence eyestrain in wig makers. Work stations that make workers uncomfortable, such as lights that are half a meter away from the head, make workers often feel glare in the eyes, double vision, sometimes dry eyes, heat on the head, frequent dizziness and various other complaints. This makes them look for a sitting position that is considered comfortable even though it is not ergonomic and requires more effort to see the object being worked in a small size, so that it has the potential to cause eyestrain. Moderate according to [12], good lighting is lighting that allows workers to see objects of their work carefully, quickly and without unnecessary effort, and help create a comfortable and pleasant work environment.

The results of this study are in line with the research conducted by [20], namely there is a relationship between the sitting positions of the work posture sitting with the work fatigue of the workforce of written batik at Masaran Sragen Surakarta. The thing that supports researchers to take batik craftsmen related to the alignment of this research is because batik craftsmen also have the same job characteristics as wigs, which requires a level of concentration and accuracy in work so that it often creates work positions that are not ergonomic when working.

The results of this study are in line with the research conducted by [6], namely there is a significant relationship between work attitudes and eyestrain in the tailor kampong solor in 2017. That supports researchers taking batik craftsmen related to the harmony of this research because tailors have characteristics the same job as a tailor is to do work objects that require a high level of eye accuracy and concentration so that it must be supported by a good work environment such as lighting and a good work station, in order to avoid non-ergonomic work attitudes which eventually cause work fatigue in the eyes of workers.

\section{Relationship of Workload with Work Fatigue and Eyestrain on Wig Makers at PT. SCI}

Table 2. Relationship of Workload with Work Fatigue and Eyestrain

\begin{tabular}{|c|c|c|c|c|c|c|c|c|c|}
\hline \multirow[t]{3}{*}{ Workload } & \multicolumn{6}{|c|}{ Work fatigue } & \multirow{2}{*}{\multicolumn{2}{|c|}{ Total }} & \multirow[t]{2}{*}{ p Value } \\
\hline & \multicolumn{2}{|c|}{ Mild } & \multicolumn{2}{|c|}{ Moderate } & \multicolumn{2}{|c|}{ Heavy } & & & \\
\hline & $\mathrm{n}$ & $\%$ & $\mathrm{n}$ & $\%$ & $\mathrm{n}$ & $\%$ & $\mathrm{~N}$ & $\%$ & \multirow{3}{*}{0,002} \\
\hline Mild & 10 & 20,8 & 9 & 18,8 & 1 & 2,1 & $\begin{array}{l}2 \\
0\end{array}$ & $\begin{array}{c}41, \\
7\end{array}$ & \\
\hline Heavy & 4 & 8,3 & 10 & 20,8 & $\begin{array}{l}1 \\
4\end{array}$ & 29,2 & $\begin{array}{l}2 \\
8\end{array}$ & $\begin{array}{c}58, \\
3\end{array}$ & \\
\hline Total & 14 & 29,1 & 19 & 39,6 & $\begin{array}{l}1 \\
5\end{array}$ & 31,3 & $\begin{array}{l}4 \\
8 \\
\end{array}$ & 100 & \\
\hline \multirow[t]{3}{*}{ Workload } & \multicolumn{6}{|c|}{ Eyestrain } & \multirow{2}{*}{\multicolumn{2}{|c|}{ Total }} & \multirow[t]{2}{*}{$p$ Value } \\
\hline & \multicolumn{2}{|c|}{ Mild } & \multicolumn{2}{|c|}{ Moderate } & \multicolumn{2}{|c|}{ Heavy } & & & \\
\hline & $\mathrm{n}$ & $\%$ & $\mathrm{n}$ & $\%$ & $\mathrm{n}$ & $\%$ & $\mathrm{~N}$ & $\%$ & \multirow{3}{*}{0,201} \\
\hline Mild & 10 & 20,8 & 6 & 12,5 & 4 & 8,3 & $\begin{array}{l}2 \\
0\end{array}$ & $\begin{array}{c}41, \\
7\end{array}$ & \\
\hline Heavy & 7 & 14,6 & 12 & 25,0 & 9 & $\begin{array}{c}18, \\
8\end{array}$ & $\begin{array}{l}2 \\
8 \\
\end{array}$ & $\begin{array}{c}58, \\
3\end{array}$ & \\
\hline Total & 17 & 35,4 & 18 & 37,5 & 13 & $\begin{array}{c}17, \\
17\end{array}$ & $\begin{array}{l}4 \\
8 \\
\end{array}$ & 100 & \\
\hline
\end{tabular}

Table 2 on the work fatigue category of heavy workload, there are 14 workers experienced heavy work fatigue (29.2\%), 10 workers experienced moderate work fatigue $(20.8 \%)$, and 4 people with heavy workload experienced mild work fatigue ( $8.3 \%$ ). Whereas in the category of light workload there was 1 worker experienced severe work fatigue $(2.1 \%), 9$ workers experienced moderate work fatigue $(18.8 \%)$, and 10 workers experienced mild work fatigue $(20.8 \%)$. Chi-square test results obtained $\mathrm{p}$ value significance value of $0.002<0.05$. As a result, there is a relationship between workload and work fatigue in PT. SCI.

In the eyestrain category of heavy workload, there were 9 workers experienced severe eyestrain $(18.8 \%), 12$ workers experienced moderate eyestrain $(25.0 \%)$, and 7 workers experienced mild eyestrain $(14.6 \%)$. Whereas in the category of light workload there were 4 workers experiencing severe eyestrain $(8.3 \%), 6$ workers with light workloads experienced moderate eyestrain $(12.5 \%)$, and 10 workers experienced mild eyestrain $(20,8 \%)$,). Chi square test results obtained $\mathrm{p}$-value significance value $0.201>0.05$. As a result, there is no relationship between workload and eyestrain in PT. SCI.

According to Tarwaka, et al 2004 [19], the human body is designed to be able to carry out daily activities. At work, a person will receive load or burden from outside his body. The burden can be physically or mentally. Each workload must be in accordance with the physical abilities, cognitive abilities, and limitations of humans who accept the burden. The workload discussed in this study is more directed at the mental workload received by wigs.

The results showed there was a relationship between workload and work fatigue and eyestrain in wigs. This is because workers feel they have a heavy workload because they are chased by targets and time. Wig makerss must work on targets within one week with workloads that have a level of accuracy and have a high level of concentration. This causes some workers to feel unable to catch up with the target, and the responsibilities given are so heavy that they make their psychic decrease to do their work. Psychic decline means that the worker has experienced work exhaustion due to a decrease in motivation and productivity at work [21]. Mental workload, according to [13] cited in [16], is a workload that relies on thoughts and feelings for example in this study wigs have the 
responsibility of how to pursue targets within the time specified by the company with the aim of getting a salary and also bonus according to what is done. As for other things that affect workload with work fatigue, namely the age of workers who are mostly at a young age where they want to work and get the wages or salaries provided in accordance with what is done to meet their life needs. Wages that do not compensate for the workload given as what is done alone are calculated for the usual salary. This makes workers feel tired and tired of their work.

The results of this study are similar with the research conducted by [2]; there is a significant relationship between workload and work exhaustion in convection tailor workers in the city of Kendari.

Most of the workers felt eye complaints in the form of sore eyes, dryness, blurred appearance, double-sighted views and no focus on an object. This is more likely due to the non-ergonomic lighting that requires the eyes to work harder so as to cause intensive stress which can affect the accommodation muscles in the eye causing work fatigue in the eyes [8]. Moderating the perceived workload does not affect the worker's eyestrain, this can be seen from the results of statistical tests where there is no relationship between workload and eyestrain. Workload felt by workers is considered a challenge that must be done to be able to get an increase in workers' income besides the worker must reach the target or exceed the target. Even though they feel uncomfortable with what is done but to meet the needs of life, they still work on what they are responsible for regardless of the effect they have on working. Feelings of pursuing targets with the aim of getting salaries and bonuses to meet needs are greater than the feeling of quitting their jobs. Because according to them the workload received must be quickly resolved to get what they want. This also makes them work harder without seeing the impact of work.

The results of this study are not in line with the research conducted by [4]; there is a significant relationship between workload and eyestrain on Air Traffic Control (ATC) officers of Ahmad Yani Airport, Semarang

\section{Relationship of Lightning with Work Fatigue and Eyestrain at Wig Makers at PT. SCI.}

Table 3. Relationship of Lightning with Work Fatigue and Eyestrain Eyestrain

\begin{tabular}{|c|c|c|c|c|c|c|c|c|c|}
\hline \multirow[t]{3}{*}{ Lighting } & \multicolumn{6}{|c|}{ Work fatigue } & \multicolumn{2}{|c|}{ Total } & $P$ \\
\hline & \multicolumn{2}{|c|}{ Mild } & \multicolumn{2}{|c|}{ Moderate } & \multicolumn{2}{|c|}{ Heavy } & & & \\
\hline & $\mathrm{n}$ & $\%$ & $\mathrm{n}$ & $\%$ & $\mathrm{n}$ & $\%$ & $\mathrm{n}$ & $\%$ & \\
\hline Good & 13 & 27,1 & 6 & 12,9 & 4 & 8,3 & 23 & 47,9 & \multirow[t]{2}{*}{0,002} \\
\hline \multirow[t]{2}{*}{ Not good } & 1 & 2,1 & 13 & 27,1 & $\begin{array}{l}1 \\
1\end{array}$ & 22,9 & 29 & 41,7 & \\
\hline & 14 & 29,2 & 19 & 39,6 & $\begin{array}{l}1 \\
5\end{array}$ & 31,3 & 48 & 100 & \\
\hline \multirow[t]{3}{*}{ Lighting } & \multicolumn{6}{|c|}{ Eyestrain } & \multicolumn{2}{|c|}{ Total } & $\begin{array}{c}P \\
\text { value }\end{array}$ \\
\hline & \multicolumn{2}{|c|}{ Mild } & \multicolumn{2}{|c|}{ Moderate } & \multicolumn{2}{|c|}{ Heavy } & & & \\
\hline & $\mathrm{n}$ & $\%$ & $\mathrm{n}$ & $\%$ & $\mathrm{n}$ & $\%$ & $\mathrm{n}$ & $\%$ & \\
\hline Good & 13 & 27,1 & 5 & 10,4 & 5 & 10,4 & 23 & 47,9 & 0,004 \\
\hline
\end{tabular}

Table 3 on the work exhaustion of poor lighting category, there were 11 workers experienced severe work fatigue (22.9\%), 13 workers experienced moderate work fatigue (27.1\%), and 1 worker experienced mild work fatigue (2.1 $\%)$. Whereas in the good lighting category there were 4 workers experiencing severe work fatigue $(8.3 \%), 6$ workers experienced moderate work fatigue $(12.9 \%)$, and 13 workers experiencing mild work fatigue $(27.1 \%)$. Chi square test results obtained a significance value of $\mathrm{p}$-value $0.002<0.05$. As a result, there is a relationship between lighting and work fatigue on PT. SCI.

In the eyestrain category of poor lighting, there were 8 workers experienced severe eyestrain (16.7\%), 13 workers experienced moderate eyestrain $(27.1 \%)$, and 4 workers experienced mild eyestrain $(8.3 \%)$. Whereas in the good lighting category there were 5 workers experienced severe eyestrain $(10.4 \%), 5$ workers experiencing moderate eyestrain $(10.4 \%)$, and 13 workers experiencing mild eyestrain $(27.1 \%)$. Chi square test results obtained $\mathrm{p}$-value significance value $0.004<0.05$. As a result, there is no relationship between lighting and eyestrain in PT. SCI.

Wig makers have a work object that requires a high level of precision and eye accuracy. A good lighting is needed to support them during their work. The results obtained when conducting research are many workers do not receive good lighting and have less standards than those who get good lighting. Good lighting must be in accordance with the standards set by the Indonesian Ministry of Health Decree No. 1405 of 2015, concerning the health requirements of the office and industrial work environment that meets the requirements if the measurement results have a value of 300-500 Lux. The intensity of lighting is one component so that the workforce can do their work and observe the object of the Moderate work done clearly, quickly, comfortably and safely. The intensity of lighting in the workplace must be adequate and in accordance with standards so that when the workforce does its work, it does not create risks that can endanger the workforce [6].

allows workers to see objects that are done clearly, without requiring unnecessary effort. So that workers do not need to need more work so that they avoid work fatigue. The results of research that have been done show that wigs have experienced work fatigue caused by lights that are half a meter away from the head position so that workers often feel dizzy and hot in the head area. This is what causes workers to need more effort to get a position that is considered comfortable when working, without seeing the effect caused by a sitting position that is not ergonomic. The ergonomic sitting position causes tension in the muscles, causing work fatigue while working.

The results of this study are in line with the research conducted [17], namely that there is a significant relationship between lighting and work exhaustion in the tailor of the kampong Solor in 2017. The reason researchers took tailors because wigs have the same job characteristics as tailors that have work objects who are careful and have high eye concentration that affects the accommodation power of the eye which eventually results in work fatigue in the eyes of the worker.

The results found that there is a relationship between 
lighting intensity and eyestrain in wig makerss. According to the researchers, this happened because the lighting received by most of the wig makerss did not fulfill proper lighting standards. The distance between the lamp and the head also affects eyestrain such as frequent feeling of heat in the head area, double-sighted views, watery eyes, glare and various other complaints. Some of the early symptoms of eyestrain include dry eyes, burning eyes, blurred vision, double vision, headache, pain in the neck, shoulders and back muscles [6].

The intensity of artificial lighting is supporting the fulfillment of the intensity of lighting in a room. If the intensity of lighting in a room is not met then the possibility of workers to experience work accidents will be even greater. The number of dead lights is one of the factors that can affect the intensity of lighting. Poor distribution of light in the work environment can cause eyestrain. Unbalanced lighting distribution reduces the efficiency of sharp vision and the ability to distinguish contrast [14]. The results of this study found that there were several lights that died so that workers needed more effort to see the object being worked on. This creates intensive stress on the eye's function on muscle accommodation so that it can cause eyestrain.

[8] stated that eyestrain caused by stress that occurs in the function of vision. Stress in accommodation muscles can occur when someone attempts to look at small objects at close range for a long time. In such conditions, the eye muscles will work continuously and are more forced. The tension of accommodating muscles (ciliary muscles) is greater so that there is an increase in lactic acid and as a result eyestrain, eye stress, stress on the retina can occur if there is excessive contrast in the visual field and a long time of observation.

The results of this study are in line with the research conducted [3]; there is a significant relationship between the intensity of lighting and eyestrain in the seamstress workers in the informal business at sector President Pasar 45, Manado. The reason researchers took tailors because fake hair workers have the same work object that has a high level of accuracy and concentration on the eyes, so that if it is not supported by good lighting it will cause work fatigue in the eyes of workers.

\section{CONCLUSION}

There is relationship between work attitude with work fatigue and eyestrain of wig makerss at PT SCI. There is relationship between workload with work fatigue and no relationship between workload with eyestrain of wig makerss at PT SCI. There is relationship between lighting with work fatigue and eyestrain of wig makers at PT SCI

\section{REFERENCES}

[1] Andreani, M.U.D \& Paskarini, I. Health Promotion Journal. Work Attitudes Related to Subjective Complaints on Tailors on Patua Street, Surabaya. Airlangga University: Vol 1 (2): 201-208 [ cited 2018 Marc $7 . \quad$ Available from: http://journal.unair.ac.id/filerPDF/jupromkesa35197c880fu 11.pdf .

[2] Patala, W. Factors Related to Job Work fatigue in Convection Tailor Workers in Kendari City Tahun 2016. [cited 2018 Pebruary 2] Available from: http://sitedi.uho.ac.id/uploads_sitedi/J1A113209_sitedi_A BSTRAK\%20WIKA\%20PATALA\%20(J1A113209).pdf. [3] Puha, T. Rattu, J. Kawatu, P. Relation of Lighting Intensity with Eye Work fatigue on Informal Business of Tailor Workers in Kompleks Gedung President Pasar 45 Kota Manado. Universitas Sam Ratulangi. [cited 2018 Pebruary 21] Available from: http://fkm.unsrat.ac.id/wpcontent/uploads/2014/11/tifani.pdf.

[4] Putri, O. Purwaningsi, R. Rumita, R. 2013. Effect of Mental and Eye Work fatigue Workloads on ATC Officer Alertness Ahmad Yani Semarang. Universitas Diponegoro Semarang. [cited 2018 Pebruary 27] Available from:

https://ejournal3.undip.ac.id/index.php/ieoj/article/view/42 50.

[5] Salawati, L. Occupational Disease and Prevention. Jurnal Kedokteran Syah Kuala. 2015; 15 No 2, 91-95, 1412. 1026.

[6] Wiyanti, N. Martiana, T. The Relationship between Information Intensity and Eye Fatigue in Written Batik Craftsmen. The Indonesian Journal of Occupational Safety and Health Universitas Airlangga. 2015; 4 (2): 144 154.

[7] Barnes, R.M. 1980. Motion and Time Study Design and Measurement of Work. $7^{\text {th }}$ edition. New York : John Wiley \& Sons. London, 1992.

[8] Ilyas. Functions and Measurement of Learning Achievement. Pustaka Belajar. Yogyakarta;2008.

[9] McCormick,E.J and M.S.Sanders. Human Factor in Engineering and Design. New York : McGraw Hill Book Company; 1994.

[10] Notoadmodjo, S. Research Method. Jakarta: Rineka Cipta; 2012

[11] Santoso, G. Human Ergonomics, Equipment and Environment. Prestasi Pustaka Publisher: Sidoarjo; 2004.

[12] Summa'mur. Corporate Hygiene and Occupational Health. 2th ed. CV Segung Seto Jakarta; 2014.

[13] Tarwaka, Sholicul, Sudiajeng, L. Ergonomics for occupational safety and health for productivity. Surakarta: UNIBA Press; 2004.

[14] Firmansyah, F. The Efffect of Light Intensity on Eye Work fatigue of Labor in Packing Section of PT. Ikapharmindo Putramas Jakarta Timur. [skripsi]. Surakarta; Universita Sebelas Maret; 2010.

[15] Masitoh, D. Analysis of Body Posture with the Rula Method on Welding Workers in Sub Assy Area of PT. Fuji Technica Indonesia Karawang. [skripsi]. Surakarta; Universitas Sebelas Maret; 2016.

[16] Monkoginta, L.M. Workload Assessment and Job Stress Levels at Employees in PT. Dosa Ni Roha Kupang Tahun 2016. [skripsi]. Kupang; Fakultas Kesehatan Masyarakat Universitas Nusa Cendana; 2016

[17] Odi, K.D. Relationship between Work Attitudes, Lighting and Temperature on Work fatigue and Eye Work 
[20] Wati, D.H. The Relationship of Sitting Work

fatigue on Tailors in Solor Village Kupang 2017. [skripsi]. Kupang; Fakultas Kesehatan Masyarakat Universitas Nusa Cendana; 2017.

[18] Seko, F.A. Factors Associated with Eye Work fatigue on Tailor in Kuanino Subdistrict Kota Raja District Kupang City [skripsi]. Kupang; Fakultas Kesehatan Masyarakat Universitas Nusa Cendana; 2014.

[19] Umiyati. Factors Associated with Job Work fatigue in Informal Business Sector of Tailor Workers in Ketapang Cipondoh Area Tangerang. [skripsi]. Jakarta; Universitas Islam Negeri Syarif Hidayatullah; 2010.
Posture with the Work fatigue of Batik Tulis Workers in Masaran Sragen. [skripsi]. Surakarta; Universitas Sebelas Maret; 2016.

[21] Manuaba, I.B.A. 2005. Total Ergonomics in All Work Systems Is Absolutely Necessary to Achieve Humane Work Systems and Competitive Product Quality. Keynote Address: Kongres IV Ikatan Sarjana Teknik Industri. Palembang: 24-25 Juni. 